GRASAS Y ACEITES 70 (1)

January-March 2019, e288

ISSN-L: 0017-3495

https://doi.org/10.3989/gya.0463181

\title{
Variations in fatty acid composition and oxidative stability of hazelnut (Corylus avellana L.) varieties stored by traditional method
}

\author{
H. Karaosmanoğlu $\mathrm{u}^{\mathrm{a}, \varpi}$ and N.Ş. Üstün ${ }^{\mathrm{b}}$ \\ ${ }^{a}$ Giresun University, Technical Vocational School, Hazelnut Expertise Programme Giresun/Turkey \\ ${ }^{b}$ Ondokuz Mayis University, Faculty of Engineering, Department of Food Engineering, Samsun/Turkey \\ ${ }^{\square}$ Corresponding author: hasan.karaosmanoglu@giresun.edu.tr
}

Submitted: 18 April 2018; Accepted: 13 July 2018

SUMMARY: In this study, the changes in fatty acid composition, peroxide number, free fatty acids, oleic acid/ linoleic acid $(\mathrm{O} / \mathrm{L})$ and iodine value (IV) were investigated during the traditional storage of hazelnuts. The samples were selected from Giresun Quality Tombul, Kara and Sivri hazelnut varieties with economical prescription. Samples were stored according to the conventional methods in external interference-free warehouses until the next harvest time. At the end of storage, the amount of oleic acid in all varieties increased while the amount of linoleic acid decreased. Even though an increase in the free fatty acids and peroxide number in all types of hazelnuts during storage was determined, the values were considerably lower than the rancidity limits at the end of the storage period. As a result of the study it was observed that the hazelnut shell is an important preservative during storage and that hazelnuts can be preserved until the next harvest period under simple storage conditions.

KEYWORDS: Fatty Acid; Free Fatty Acid; Iodine Value; Oxidative Stability; Peroxide Number; Storage

RESUMEN: Variación en la composición de ácidos grasos y estabilidad oxidativa de variedades de avellana (Corylus avellana $L$.) almacenadas por métodos tradicionales. En este estudio se investigaron los cambios en la composición de ácidos grasos, en el índice de peróxidos, la acidez libre, la relación oleico/linoleico (O/L) y el índice de yodo (IV) durante el almacenamiento tradicional de avellanas. Las muestras fueron seleccionadas de las variedades Giresun Quality Tombul, Kara y Sivri. Las muestras se almacenaron según los métodos convencionales en depósitos libres de interferencia hasta la siguiente cosecha. Al final del almacenamiento, la cantidad de ácido oleico en todas las variedades aumentó mientras que la cantidad de ácido linoleico disminuyó. Aunque se constató un aumento de la acidez libre y del índice de peróxidos, en todos los tipos de avellanas durante el período de almacenamiento, los valores fueron considerablemente menores que los límites de rancidez al final del almacenamiento. Como resultado del estudio, se observó que la cáscara de avellana es un conservante importante durante el almacenamiento y la avellana se puede conservar hasta la siguiente cosecha en condiciones de almacenamiento simple.

PALABRAS CLAVE: Acidez libre; Ácido graso; Almacenamiento; Estabilidad oxidativa; Índice de peróxido; Índice de yodo

ORCID ID: Karaosmanoğlu H https://orcid.org/0000-0002-4652-9861, Üstün NŞ https://orcid.org/0000-0003-2165-9245

Citation/Cómo citar este artículo: Karaosmanoğlu H, Üstün NŞ. 2019. Variations in fatty acid composition and oxidative stability of some hazelnut (Corylus avellana L.) varieties stored by traditional method. Grasas Aceites 70 (1), e288. https://doi.org/10.3989/gya.0463181

Copyright: (C2019 CSIC. This is an open-access article distributed under the terms of the Creative Commons Attribution 4.0 International (CC BY 4.0) License. 


\section{INTRODUCTION}

The hazelnut is a hard-shelled fruit belonging to the genus Corylus in the Betulaceae family of the order Fagales in the plant kingdom (Kurt, 2004). Anatolia is the native land of hazelnuts, where the natural span of the most valuable wild species and source of culture varieties is located (Turan, 2007). At present, the nut is among Turkey's major export products, mainly from the provinces of Giresun and Ordu in the Black Sea Region and it is the only major source of livelihood for the people in some areas (Şahin et al., 1990). Turkey is the world's leading hazelnut exporter $(70 \%)$ and supplier $(79 \%)$, followed by Italy, Spain, Portugal, the United States and Azerbaijan, respectively (Karaosmanoğlu and Üstün, 2017).

In the food industry hazelnuts are mostly used in the production of pastry, bakery products, ice cream and milk products, confectionery and chocolate products. They can also be added to breakfast cereals, breads, yogurt, soups, salads and main dishes (Simsek and Aykut, 2007). The hazelnut is an important food for human nutrition in terms of fat, protein, carbohydrates, vitamins and mineral contents and fatty acid composition (Alasalvar et al., 2003; Alasalvar et al., 2009). Hazelnuts contain approximately $55-71 \%$ fat, which varies according to variety, and most of it is composed of unsaturated fatty acids $(85-90 \%)$. Oleic acid is the major fatty acid in unsaturated fatty acids (74.9-84.3\%) and the amount in hazelnuts is higher than that of pistachios, almonds, cashew nuts, chestnuts and walnuts (Koç Güler et al., 2017b). Besides being a very popular nut because of its unique taste and texture, the hazelnut contains many compounds such as mono-unsaturated fatty acids, phytosterols (mainly $\beta$-sitosterol) and antioxidant phenols, which help protect human health (Oliveira 2008; Gunes et al., 2010; Ghirardello et al., 2016). In addition to helping to prevent obesity because of its high dietary fiber content, it is also thought to help to prevent hypertension, coronary heart disease, prostate cancer and intestinal diseases (Mexis and Kontominas, 2009).

Hazelnuts are classified into 2 groups according to quality. Tombul hazelnuts have a high fat content, intense aroma and flavor and high pellicle-removal ratio. They are grown in Giresun and are classified as Giresun Quality (first quality) and other varieties grown in Giresun and all hazelnuts grown outside Giresun are classified as Levant Quality (second quality) (Alasalvar et al., 2010).

Traditionally, hazelnuts harvested in August and September are first left to sun-dry up to the moisture level of $5-6 \%$, then the green peels, called zuruf, are separated. Dried hazelnuts are stored in jute sacks in completely external environmentdependent warehouses where no temperature or humidity adjustments are made by the producers until they are ready to be processed.There have been few studies in the literature with the purpose of examining the changes in fatty acids during the storage of shelled hazelnuts, although there are studies on controlled storage or the second quality hazelnut was stored (Koyuncu, 2004; Koyuncu et al., 2005; Ghirardello et al., 2013).

In this study, the changes in some chemical properties during the traditional storage of commercially important Kara and Sivri varieties along with Giresun Quality Tombul were investigated.

\section{MATERIALS AND METHODS}

\subsection{Materials and reagents}

In the study, commercially important varities such as the Tombul variety, which is also known as 'Yağlı findık' by the local people, Kara and Sivri varieties were analyzed. Specimens were harvested from hazelnut groves in Akköy İkisu, the Batlama valley of the Giresun province (Turkey) in August. The geographical coordinates of the grove where the samples were taken are 40 degrees 51 minutes 38.85 seconds North, 38 degrees 18 minutes 56.66 seconds East. Harvested hazelnuts were sun-dried on the concrete threshing floor, on jute matting in accordance with completely traditional methods. Each of the dried hazelnut varieties was completely filled into $80 \mathrm{~kg}$ jute sacks and stored in a warehouse whose temperature and humidity cannot be externally adjusted for approximately one year until the next harvest time. During the storage period, the temperature of the warehouse environment ranged from 7.9 to $24.8^{\circ} \mathrm{C}$ and the relative humidity ranged from 47.5 to $79.4 \%$. The sacks were placed on wooden planks in order to prevent contact with the concrete floor. The first specimens were taken at the end of the blending process in September and the others were taken in November, January, March, May and August. Samples were taken from the sacks and placed in plastic bags where they were kept at $-20{ }^{\circ} \mathrm{C}$ in a deep freezer until analysis.

The analytical-grade chemical substances used in the study were: hydrochloric acid, methanol, ethyl alcohol, chloroform, calcium chloride, iso-octane, potassium hydroxide, diethyl ether, sodium hydroxide, potassium iodide, acetic acid, sodium thiosulfate and a methyl orange indicator, all provided by Merck (Germany), Sigma (ABD), Carlo Erba (France) firms. 37 fatty acid methyl ester mixtures were supplied by Bellefonte PA (USA).

\subsection{Methods}

Hazelnut oil extraction. The extraction of lipids from hazelnut samples was done according to the method used by Evren (2011) (Bligh and Dyer, 
1959). After the addition of $50 \mathrm{ml}$ of chloroform: methanol (GC purity) (2:1 v/v) to $10 \mathrm{~g}$ of sample, $10 \mathrm{ml}$ of $0.01 \mathrm{M} \mathrm{CaCl}_{2}$ solution were added dropwise to the resulting mixture. The solution was filtered through ordinary filter paper. The resulting filtrate was placed in teflon tubes and centrifuged at $2000 \mathrm{~g}$ for 15 minutes. The bottom phase of the centrifuge tube was transferred to a socket volumetric flask using a pipette and the solvent phase was separated on a rotary evaporator to obtain oil. In order to obtain fatty acid methyl esters (ISO, 1978), $0.5 \mathrm{~g}$ of oil was weighed into the flask and $4 \mathrm{ml}$ of iso-octane and $2 \mathrm{ml}$ of methanolic $\mathrm{KOH}$ solutions were added and then shaken for 30 seconds. The bottom phase of the centrifuge tube was transferred to a socket volumetric flask using a pipette and the solvent phase was separated off on a rotary evaporator so the oil was obtained.

Fatty acid composition. To obtain the fatty acid methyl esters (ISO, 1978), $0.5 \mathrm{~g}$ of oil was weighed into an erlenmayer flask and mixed with $4 \mathrm{ml}$ of isooctane and $2 \mathrm{ml}$ of a methanolic $\mathrm{KOH}$ solution, and shaken for 30 seconds. Then, the erlenmayer was closed and left in the dark for 6 minutes. At the end of the period, 2 drops of $1 \%$ methyl orange indicator were added and the solution was titrated with $1 \mathrm{M}$ $\mathrm{HCl}$ until a pink color appeared. After the contents rested for 15 minutes, the colorless upper layer was transfered into glass vials and analyzed in GC. The composition of fatty acids was determined using Shimadzu brand (Model GC-2010, Japan) gas chromatography with a flame ionization detector (FID) and TR-CN100 column (60 m x $0.25 \mathrm{~mm}$ I.D., 0.20 $\mu \mathrm{m})$ (Teknokroma, Spain). The injector and detector temperatures were set at $250{ }^{\circ} \mathrm{C}$. The amount of sample injected was $1.0 \mu$ and helium was used as carrier gas at a pressure of $200 \mathrm{kPa}$. Injection was performed at a ratio of $1: 100$. The column temperature was held at $90{ }^{\circ} \mathrm{C}$ for 7 minutes, then increased to $240{ }^{\circ} \mathrm{C}$ at $5{ }^{\circ} \mathrm{C} / \mathrm{min}$. Finally, it was held at $240{ }^{\circ} \mathrm{C}$ for 15 minutes. Fatty acids were identified by comparison with the time of arrival of the FAME mixture (Supelco 37 Component FAME Mixture, Cat. No. 18919-1AMP, Bellefonte PA, USA) consisting of 37 standard components (Saricaoglu and Turhan, 2013).

Free fatty acids. Two handfuls of hazelnut sample were put in a cloth bag and hazelnut oil was obtained with the help of a cold press. This oil was placed in a $10 \mathrm{ml}$ centrifuge tube and the sediments in the oil were allowed to settle. About $5 \mathrm{~g}$ of fat were transferred to a $250 \mathrm{ml}$ Erlenmeyer flask with a known tare weight. $50 \mathrm{ml}$ of a mixture of ether:ethanol (1/1, $\mathrm{v} / \mathrm{v}$ ) was added and shaken, 2-3 drops of 1\% phenolphthalein indicator were dropped and the mixture was titrated with $0.1 \mathrm{~N} \mathrm{NaOH}$ solution until a light pink color was obtained. The amount of free fatty acid in oleic acid was calculated by the following formula: \% Free Fatty Acid $=[(\operatorname{SxFx} 0.0282) / \mathrm{M}] \mathrm{x}$
100, S: Amount of $\mathrm{NaOH}$ spent in the titration, $\mathrm{F}$ : Factor of $0.1 \mathrm{~N} \mathrm{NaOH}$ solution, $\mathrm{M}$ : Amount of oil used (AOCS, 1990).

Peroxide value. Two handfuls of hazelnut sample were put in a cloth bag and the hazelnut oil was obtained with the help of cold press. About 5-5.09 g oil were weighed into a $250 \mathrm{ml}$ erlenmeyer which was tared and wrapped with aluminum foil. $30 \mathrm{ml}$ of an acetic acid:chloroform (3:2, v/v) mixture were added and mixed. $0.5 \mathrm{ml}$ of a saturated potassium iodide solution was added. It was shaken for a minute and left in the dark. At the end of the shaking period, $30 \mathrm{ml}$ of distilled water and $0.5 \mathrm{ml}$ of $1 \%$ starch solution were added. The solution was titrated with $0.01 \mathrm{~N}$ sodium thiosulfate solution until a clear cream color was formed and the peroxide number was calculated according to the following formula: Peroxide Number $\left(\mathrm{meq} \mathrm{O}_{2} / \mathrm{kg}\right.$ fat $)=[(\mathrm{SxNxF}) / \mathrm{M}]$ $\mathrm{x} 1000, \mathrm{~S}$ : the amount of sodium thiosulfate spent in the titration, $\mathrm{F}$ : the factor of the solution, $\mathrm{N}$ : the normality of the sodium thiosulfate solution, $\mathrm{M}$ : the amount of fat (g) (AOAC, 1990).

Iodine value and OIL. Oxidative stability was calculated with a specific formula given as iodine value (palmitoleic acid * 1.901) + (oleic acid * 0.899) + (linoleic acid * 1.814) + (linolenic acid *2.737) and expressed as oleic acid/linoleic acid (Belvisio et al., 2017).

\subsection{Statistical evaluation}

For the analysis of data, one-way ANOVA for time and variety, two-way ANOVA to determine time and variety interaction, and the Tukey HSD test to determine different averages were used. The analytical results were evaluated statistically using the SPSS 21 statistical software (SPSS Inc., Chicago, USA).

\section{RESULTS AND DISCUSSION}

\subsection{Composition of fatty acids}

The changes in fatty acid composition of hazelnuts during storage are given in Table 1. In all hazelnut varieties, the dominant saturated fatty acid was palmitic acid followed by stearic acid. In all varieties, the highest unsaturated fatty acid was identified as oleic acid, followed by linoleic acid. Similar findings were reported in the studies of Oliveira et al., (2008), Alasalvar et al., (2010), Göncüoğlu Taş and Gökmen (2015), Kalkisim et al., (2016).

At the beginning of storage, the highest amount of palmitic acid was found in Sivri $(5.60 \%)$, the lowest in Tombul $(4.63 \%)$ and the difference between varieties was found to be significant $(p<0.001)$. The amount of palmitic acid, which was initially $4.63 \%$, increased to $4.71(p<0.01)$ at the end of storage, but there was no change in other varieties. It was determined that the amount of palmitic acid decreased from $5.74 \%$ to 
TABLE 1. Changes in fatty acid composition of the studied hazelnut varieties during storage (\%)

\begin{tabular}{|c|c|c|c|c|c|c|c|c|c|c|}
\hline \multirow[b]{2}{*}{ Parameters } & \multirow[b]{2}{*}{ Cultivar } & \multicolumn{6}{|c|}{ Period (months) } & \multirow[b]{2}{*}{$p \mathbf{p}$} & \multirow[b]{2}{*}{$p c$} & \multirow[b]{2}{*}{$p \mathbf{p} \times p c$} \\
\hline & & $\mathbf{0}$ & 2 & 4 & 6 & 8 & 11 & & & \\
\hline \multirow{3}{*}{$\begin{array}{l}\text { Palmitic } \\
\text { acid (16:0) }\end{array}$} & Tombul & $4.63 \pm 0.21 \mathrm{cB}$ & $4.64 \pm 0.01 \mathrm{bB}$ & $4.61 \pm 0.01 \mathrm{cB}$ & $4.76 \pm 0.00 \mathrm{cA}$ & $4.65 \pm 0.01 \mathrm{bB}$ & $4.71 \pm 0.01 \mathrm{cA}$ & $* *$ & $* * *$ & $* *$ \\
\hline & Kara & $4.83 \pm 0.21 \mathrm{bA}$ & $4.80 \pm 0.00 \mathrm{bA}$ & $4.83 \pm 0.01 \mathrm{bA}$ & $4.87 \pm 0.01 \mathrm{bA}$ & $4.75 \pm 0.08 \mathrm{bA}$ & $4.85 \pm 0.01 \mathrm{bA}$ & & & \\
\hline & Sivri & $5.60 \pm 0.14 \mathrm{aA}$ & $5.51 \pm 0.09 \mathrm{aA}$ & $5.57 \pm 0.01 \mathrm{aA}$ & $5.57 \pm 0.02 \mathrm{aA}$ & $5.61 \pm 0.00 \mathrm{aA}$ & $5.62 \pm 0.01 \mathrm{aA}$ & & & \\
\hline \multirow{3}{*}{$\begin{array}{l}\text { Palmitoleic } \\
\text { acid (16:1) }\end{array}$} & Tombul & $0.11 \pm 0.00 \mathrm{bA}$ & $0.11 \pm 0.00 \mathrm{bA}$ & $0.11 \pm 0.00 \mathrm{bA}$ & $0.11 \pm 0.00 \mathrm{cA}$ & $0.11 \pm 0.00 \mathrm{bA}$ & $0.11 \pm 0.00 \mathrm{cA}$ & NS & $* * *$ & NS \\
\hline & Kara & $0.13 \pm 0.00 \mathrm{bA}$ & $0.13 \pm 0.00 \mathrm{bA}$ & $0.13 \pm 0.00 \mathrm{bA}$ & $0.14 \pm 0.07 \mathrm{bA}$ & $0.13 \pm 0.00 \mathrm{bA}$ & $0.13 \pm 0.00 \mathrm{bA}$ & & & \\
\hline & Sivri & $0.17 \pm 0.00 \mathrm{aA}$ & $0.19 \pm 0.02 \mathrm{aA}$ & $0.17 \pm 0.00 \mathrm{aA}$ & $0.17 \pm 0.00 \mathrm{aA}$ & $0.17 \pm 0.00 \mathrm{aA}$ & $0.18 \pm 0.01 \mathrm{aA}$ & & & \\
\hline \multirow{3}{*}{$\begin{array}{l}\text { Stearic } \\
\text { acid (18:0) }\end{array}$} & Tombul & $2.55 \pm 0.00 \mathrm{aE}$ & $2.63 \pm 0.01 \mathrm{aC}$ & $2.66 \pm 0.01 \mathrm{aB}$ & $2.67 \pm 0.01 \mathrm{aB}$ & $2.60 \pm 0.00 \mathrm{aD}$ & $2.71 \pm 0.00 \mathrm{aA}$ & $* * *$ & $* * *$ & $* * *$ \\
\hline & Kara & $2.14 \pm 0.01 \mathrm{cA}$ & $2.03 \pm 0.01 \mathrm{cD}$ & $2.10 \pm 0.00 \mathrm{cBC}$ & $2.06 \pm 0.00 \mathrm{cCD}$ & $1.99 \pm 0.02 \mathrm{cE}$ & $2.14 \pm 0.00 \mathrm{bAB}$ & & & \\
\hline & Sivri & $2.27 \pm 0.00 \mathrm{bA}$ & $2.23 \pm 0.06 \mathrm{bAB}$ & $2.29 \pm 0.00 \mathrm{bA}$ & $2.17 \pm 0.01 \mathrm{bBC}$ & $2.12 \pm 0.00 \mathrm{bC}$ & $2.11 \pm 0.00 \mathrm{cC}$ & & & \\
\hline \multirow{3}{*}{$\begin{array}{l}\text { Oleic acid } \\
\text { (18:1) }\end{array}$} & Tombul & $83.67 \pm 0.01 \mathrm{bD}$ & $83.65 \pm 0.04 \mathrm{bD}$ & $84.34 \pm 0.03 \mathrm{bA}$ & $84.18 \pm 0.03 \mathrm{aBC}$ & $84.22 \pm 0.01 \mathrm{bB}$ & $84.07 \pm 0.04 b C$ & $* * *$ & $* * *$ & $* * *$ \\
\hline & Kara & $81.06 \pm 0.08 \mathrm{cC}$ & $81.25 \pm 0.04 \mathrm{cABC}$ & $81.25 \pm 0.01 \mathrm{cBC}$ & $81.55 \pm 0.02 \mathrm{bA}$ & $81.04 \pm 0.16 \mathrm{cC}$ & $81.51 \pm 0.03 \mathrm{cAB}$ & & & \\
\hline & Sivri & $84.32 \pm 0.03 \mathrm{aC}$ & $84.13 \pm 0.09 \mathrm{aC}$ & $85.00 \pm 0.08 \mathrm{aA}$ & $84.24 \pm 0.03 \mathrm{aC}$ & $84.65 \pm 0.01 \mathrm{aB}$ & $85.08 \pm 0.02 \mathrm{aA}$ & & & \\
\hline \multirow{3}{*}{$\begin{array}{l}\text { Linoleic } \\
\text { acid (18:2) }\end{array}$} & Tombul & $8.67 \pm 0.01 \mathrm{bA}$ & $8.57 \pm 0.04 \mathrm{bA}$ & $7.93 \pm 0.01 \mathrm{bCD}$ & $7.89 \pm 0.03 \mathrm{bD}$ & $8.04 \pm 0.01 \mathrm{bB}$ & $8.02 \pm 0.03 \mathrm{bBC}$ & $* * *$ & $* * *$ & $* * *$ \\
\hline & Kara & $11.46 \pm 0.07 \mathrm{aAB}$ & $11.40 \pm 0.04 \mathrm{aAB}$ & $11.31 \pm 0.01 \mathrm{aBC}$ & $11.01 \pm 0.01 \mathrm{aC}$ & $11.70 \pm 0.21 \mathrm{aA}$ & $11.00 \pm 0.02 \mathrm{aC}$ & & & \\
\hline & Sivri & $7.28 \pm 0.02 \mathrm{cB}$ & $7.58 \pm 0.08 \mathrm{cA}$ & $6.62 \pm 0.07 \mathrm{cC}$ & $7.50 \pm 0.06 \mathrm{bA}$ & $7.07 \pm 0.05 \mathrm{cB}$ & $6.68 \pm 0.01 \mathrm{cC}$ & & & \\
\hline \multirow{3}{*}{$\begin{array}{l}\text { Arachidic } \\
\text { acid (20:0) }\end{array}$} & Tombul & $0.13 \pm 0.00 \mathrm{aA}$ & $0.14 \pm 0.00 \mathrm{aA}$ & $0.14 \pm 0.00 \mathrm{aA}$ & $0.14 \pm 0.00 \mathrm{aA}$ & $0.13 \pm 0.00 \mathrm{aA}$ & $0.13 \pm 0.00 \mathrm{aA}$ & $*$ & $* * *$ & $* *$ \\
\hline & Kara & $0.12 \pm 0.00 \mathrm{aA}$ & $0.12 \pm 0.01 \mathrm{bA}$ & $0.12 \pm 0.00 \mathrm{aA}$ & $0.12 \pm 0.00 \mathrm{aA}$ & $0.12 \pm 0.00 \mathrm{aA}$ & $0.12 \pm 0.00 \mathrm{aA}$ & & & \\
\hline & Sivri & $0.11 \pm 0.00 \mathrm{aA}$ & $0.12 \pm 0.07 \mathrm{bA}$ & $0.11 \pm 0.00 \mathrm{aA}$ & $0.11 \pm 0.00 \mathrm{aA}$ & $0.11 \pm 0.00 \mathrm{aA}$ & $0.11 \pm 0.00 \mathrm{aA}$ & & & \\
\hline \multirow{3}{*}{$\begin{array}{l}\text { Linolenic } \\
\text { acid (18:3) }\end{array}$} & Tombul & $0.17 \pm 0.01 \mathrm{aA}$ & $0.18 \pm 0.00 \mathrm{aA}$ & $0.16 \pm 0.00 \mathrm{bA}$ & $0.18 \pm 0.00 \mathrm{aA}$ & $0.18 \pm 0.00 \mathrm{aA}$ & $0.18 \pm 0.00 \mathrm{aA}$ & * & $*$ & NS \\
\hline & Kara & $0.18 \pm 0.00 \mathrm{aA}$ & $0.19 \pm 0.01 \mathrm{aA}$ & $0.19 \pm 0.01 \mathrm{aA}$ & $0.20 \pm 0.01 \mathrm{aA}$ & $0.25 \pm 0.05 \mathrm{aA}$ & $0.22 \pm 0.06 \mathrm{aA}$ & & & \\
\hline & Sivri & $0.17 \pm 0.00 \mathrm{aA}$ & $0.19 \pm 0.02 \mathrm{aA}$ & $0.17 \pm 0.00 \mathrm{abA}$ & $0.18 \pm 0.00 \mathrm{aA}$ & $0.21 \pm 0.04 \mathrm{aA}$ & $0.24 \pm 0.01 \mathrm{aA}$ & & & \\
\hline \multirow{3}{*}{$\begin{array}{l}\text { Eicosenoic } \\
\text { acid }(20: 1)\end{array}$} & Tombul & $0.08 \pm 0.00 \mathrm{aA}$ & $0.09 \pm 0.01 \mathrm{aA}$ & $0.07 \pm 0.00 \mathrm{aA}$ & $0.08 \pm 0.00 \mathrm{aA}$ & $0.08 \pm 0.01 \mathrm{aA}$ & $0.07 \pm 0.01 \mathrm{aA}$ & $* *$ & $*$ & NS \\
\hline & Kara & $0.08 \pm 0.00 \mathrm{aA}$ & $0.08 \pm 0.00 \mathrm{aA}$ & $0.08 \pm 0.00 \mathrm{aA}$ & $0.08 \pm 0.01 \mathrm{aA}$ & $0.04 \pm 0.05 \mathrm{aA}$ & $0.04 \pm 0.05 \mathrm{aA}$ & & & \\
\hline & Sivri & $0.07 \pm 0.00 \mathrm{aAB}$ & $0.08 \pm 0.01 \mathrm{aA}$ & $0.07 \pm 0.00 \mathrm{aAB}$ & $0.07 \pm 0.00 \mathrm{aAB}$ & $0.06 \pm 0.00 \mathrm{aB}$ & $0.00 \pm 0.00 \mathrm{aC}$ & & & \\
\hline
\end{tabular}

$* p<0.05, * * p<0.01, * * * p<0.001, \mathrm{NS}$ : not significant. $p_{\mathrm{p}}: p_{\text {period }}, p_{\mathrm{c}}: p_{\text {cultivar }}$. Values are expressed as mean \pm standard deviation of three replicates. Values in the same row with different capital letters (A-E) are significantly different. Values in the same column and same parameters with different lower-case letters $(\mathrm{a}-\mathrm{c})$ are significantly different. Statistical test: ANOVA and multiple comparison of means using Tukey HSD's test.

5.35\% (Ghirardello et al., 2013) in hazelnuts stored uncontrolled for 12 months but there was no change in another study carried out for 12 months (Koyuncu, 2004). No changes were detected during the storage of hazelnuts packed in a vacuum and stored for one year (Koyuncu et al., 2005). Stearic acid was found to be the 4th most abundant fatty acid in all varieties, while the highest value was determined in Tombul as $2.55 \%(p<0.001)$. Stearic acid increased to $2.71 \%$ in Tombul during storage and decreased to $2.11 \%$ from $2.27 \%$ in Sivri and unchanged in Kara $(2.14 \%)$. In one study, it was determined that the content of stearic acid in hazelnuts increased from $1.85 \%$ to $3.12 \%$ as a result of storage for 12 months (Ghirardello et al., 2013) but it did not change in another study (Koyuncu, 2004). Another study carried out on the varieties of Tombul, Palaz and Kalın Kara found no change (Koyuncu et al., 2005). At the beginning and also at the end of storage the highest amount of oleic acid was found in Sivri $(84.32 \%)$ and the lowest amount was found in Kara $(81.06 \%)(p<0.001)$ and the oleic acid amounts of all varieties increased during the storage period $(p<0.001)$. The increase is thought to be proportional due to the reduction in linoleic acid.

The highest amount of linoleic acid was detected in Kara while the lowest amount was determined in Sivri $(p<0.001)$. At the end of the storage period, the amount of linoleic acid decreased from $11.46 \%$ to $11.00 \%$ in Kara, from $8.67 \%$ to $8.02 \%$ in Tombul and from $7.28 \%$ to $6.68 \%$ in Sivri. Linoleic acid was also found to decrease in some studies where storage was carried out for 12 months (Koyuncu, 2004; Koyuncu et al., 2005). This decrease is thought to be caused by peroxidation of linoleic acid (Ghirardello et al., 2013).

Saturated fatty acid (SFA) quantities did not change in all varieties at the end of storage $(p>$ 0.05 ), but the amounts of mono unsaturated fatty acid (MUFA) increased in all varieties, while poly unsaturated fatty acid (PUFA) decreased (Table 2). This is thought to be due to a decrease in the amount of linoleic acid and an increase in the amount of 
TABLE 2. Changes in SFA, MUFA and PUFA amounts of the studied hazelnut varieties during storage (\%)

\begin{tabular}{|c|c|c|c|c|c|c|c|c|c|c|}
\hline \multirow[b]{2}{*}{ Parameters } & \multirow[b]{2}{*}{ Cultivar } & \multicolumn{6}{|c|}{ Period (months) } & \multirow[b]{2}{*}{$p \mathbf{p}$} & \multirow[b]{2}{*}{$p c$} & \multirow[b]{2}{*}{$p p \times p c$} \\
\hline & & $\mathbf{0}$ & 2 & 4 & 6 & 8 & 11 & & & \\
\hline \multirow[t]{3}{*}{ ISFA } & Tombul & $7.31 \pm 0.04 \mathrm{bA}$ & $7.41 \pm 0.01 \mathrm{bA}$ & $7.38 \pm 0.11 \mathrm{bA}$ & $7.56 \pm 0.04 \mathrm{bA}$ & $7.37 \pm 0.08 \mathrm{bA}$ & $7.53 \pm 0.07 \mathrm{bA}$ & $* *$ & $* * *$ & $* *$ \\
\hline & Kara & $7.09 \pm 0.00 \mathrm{bA}$ & $6.89 \pm 0.02 \mathrm{cBC}$ & $7.05 \pm 0.07 \mathrm{cAB}$ & $7.05 \pm 0.03 \mathrm{cAB}$ & $6.82 \pm 0.09 \mathrm{cC}$ & $7.09 \pm 0.01 \mathrm{cA}$ & & & \\
\hline & Sivri & $7.98 \pm 0.11 \mathrm{aA}$ & $7.86 \pm 0.01 \mathrm{aA}$ & $7.96 \pm 0.03 \mathrm{aA}$ & $7.85 \pm 0.07 \mathrm{aA}$ & $7.83 \pm 0.00 \mathrm{aA}$ & $7.82 \pm 0.03 \mathrm{aA}$ & & & \\
\hline \multirow[t]{3}{*}{ EMUFA } & Tombul & $83.86 \pm 0.08 \mathrm{bC}$ & $83.87 \pm 0.03 \mathrm{bC}$ & $84.53 \pm 0.01 \mathrm{bA}$ & $84.35 \pm 0.06 \mathrm{aAB}$ & $84.40 \pm 0.00 \mathrm{bAB}$ & $84.27 \pm 0.07 \mathrm{bB}$ & $* * *$ & $* * *$ & $* * *$ \\
\hline & Kara & $81.21 \pm 0.01 \mathrm{cC}$ & $81.43 \pm 0.04 \mathrm{cB}$ & $81.45 \pm 0.06 \mathrm{cB}$ & $81.73 \pm 0.06 \mathrm{bA}$ & $81.13 \pm 0.08 \mathrm{cC}$ & $81.74 \pm 0.01 \mathrm{cA}$ & & & \\
\hline & Sivri & $84.54 \pm 0.00 \mathrm{aC}$ & $84.44 \pm 0.06 \mathrm{aC}$ & $85.30 \pm 0.06 \mathrm{aA}$ & $84.50 \pm 0.14 \mathrm{aC}$ & $84.88 \pm 0.10 \mathrm{aB}$ & $85.26 \pm 0.04 \mathrm{aA}$ & & & \\
\hline \multirow[t]{3}{*}{ ¿PUFA } & Tombul & $8.82 \pm 0.03 \mathrm{bA}$ & $8.71 \pm 0.11 \mathrm{bA}$ & $8.08 \pm 0.06 \mathrm{bB}$ & $8.08 \pm 0.03 b B$ & $8.22 \pm 0.01 \mathrm{bB}$ & $8.18 \pm 0.03 \mathrm{bB}$ & $* * *$ & $* * *$ & $* * *$ \\
\hline & Kara & $11.69 \pm 0.01 \mathrm{aB}$ & $11.62 \pm 0.07 \mathrm{aB}$ & $11.48 \pm 0.01 \mathrm{aB}$ & $11.20 \pm 0.10 \mathrm{aC}$ & $12.05 \pm 0.00 \mathrm{aA}$ & $11.16 \pm 0.04 \mathrm{aC}$ & & & \\
\hline & Sivri & $7.46 \pm 0.14 \mathrm{cAB}$ & $7.69 \pm 0.00 \mathrm{cA}$ & $6.63 \pm 0.10 \mathrm{cC}$ & $7.64 \pm 0.03 \mathrm{bA}$ & $7.29 \pm 0.06 \mathrm{cB}$ & $6.90 \pm 0.13 \mathrm{cC}$ & & & \\
\hline \multirow{3}{*}{ PUFA/SFA } & Tombul & $1.21 \pm 0.01 \mathrm{bA}$ & $1.18 \pm 0.03 \mathrm{bA}$ & $1.10 \pm 0.01 \mathrm{bBC}$ & $1.07 \pm 0.00 \mathrm{bC}$ & $1.12 \pm 0.01 \mathrm{bB}$ & $1.09 \pm 0.01 \mathrm{bBC}$ & $* * *$ & $* * *$ & $* * *$ \\
\hline & Kara & $1.65 \pm 0.00 \mathrm{aB}$ & $1.68 \pm 0.01 \mathrm{aB}$ & $1.63 \pm 0.01 \mathrm{aBC}$ & $1.59 \pm 0.01 \mathrm{aC}$ & $1.77 \pm 0.03 \mathrm{aA}$ & $1.57 \pm 0.01 \mathrm{aC}$ & & & \\
\hline & Sivri & $0.94 \pm 0.01 \mathrm{cB}$ & $0.98 \pm 0.00 \mathrm{cA}$ & $0.84 \pm 0.01 \mathrm{cC}$ & $0.98 \pm 0.01 \mathrm{cAB}$ & $0.94 \pm 0.01 \mathrm{cB}$ & $0.89 \pm 0.02 \mathrm{cC}$ & & & \\
\hline \multirow[t]{3}{*}{ UFA/SFA } & Tombul & $12.68 \pm 0.06 \mathrm{bA}$ & $12.49 \pm 0.04 \mathrm{bAB}$ & $12.55 \pm 0.18 \mathrm{bAB}$ & $12.23 \pm 0.06 \mathrm{bB}$ & $12.570 .14 \mathrm{bAB}$ & $12.28 \pm 0.12 \mathrm{bAB}$ & $* * *$ & $* * *$ & $* * *$ \\
\hline & Kara & $13.10 \pm 0.00 \mathrm{aC}$ & $13.52 \pm 0.04 \mathrm{aAB}$ & $13.18 \pm 0.14 \mathrm{aBC}$ & $13.18 \pm 0.04 \mathrm{aBC}$ & $13.68 \pm 0.18 \mathrm{aA}$ & $13.10 \pm 0.03 \mathrm{aC}$ & & & \\
\hline & Sivri & $11.53 \pm 0.16 \mathrm{cA}$ & $11.72 \pm 0.01 \mathrm{cA}$ & $11.55 \pm 0.04 \mathrm{cA}$ & $11.74 \pm 0.12 \mathrm{cA}$ & $11.78 \pm 0.01 \mathrm{cA}$ & $11.79 \pm 0.06 \mathrm{cA}$ & & & \\
\hline
\end{tabular}

$* p<0.05, * * p<0.01, * * * p<0.001 . p_{\mathrm{p}}: p_{\text {period }}, p_{c}: p_{\text {cultivar }}$. Values are expressed as mean \pm standard deviation of three replicates. SFA: Saturated fatty acids, MUFA: Monounsaturated fatty acids, PUFA: Polyunsaturated fatty acids. Values in the same row with different capital letters (A-C) are significantly different. Values in the same column and same parameters with different lower-case letters (a-c) are significantly different. Statistical test: ANOVA and multiple comparison of means using Tukey HSD's test.

oleic acid at the end of storage. The highest amount of SFA and MUFA among the varieties was found in Sivri (7.98\% $-84.54 \%$ respectively) and the highest amount of PUFA was found in Kara. In one study, the amounts of the SFA, MUFA and PUFA in hazelnuts were found to be $9.75 \%, 83.70 \%$ and $6.53 \%$, respectively (Belviso et al., 2017). According to Koyuncu (2004), in hazelnuts stored for 12 months, the SFA increased from $8.14 \%$ to $8.30 \%$ and unsaturated fatty acid (UFA) decreased from $92.12 \%$ to $90.88 \%$, but the differences were not significant. In our study, the PUFA/SFA ratio decreased in all varieties and this decrease is thought to be caused by the oxidation of linoleic acid.

\subsection{Free fatty acid amounts}

During storage, free fatty acid levels increased from $0.09 \%$ to $0.45 \%$ in Tombul, from $0.11 \%$ to $0.40 \%$ in Kara and from $0.20 \%$ to $0.35 \%$ in Sivri $(p<$ 0.001 ) (Table 3). At the end of the storage period, all varieties were found to have the same level of free fatty acid $(p>0.05)$. It has been reported that as a result of 18 months' storage of in-shell Çakıldak hazelnut species, the free fatty acidity increased from $0.09 \%$ to $0.48 \%$ (Turan and Islam, 2016); whereas in a similar study it was reported to increase from $0.06 \%$ to $0.47 \%$ (Ghirardello et al., 2013). It has been reported that exceeding $0.7 \%$ of free fatty acid concentration in oleic acid in hazelnut indicates the onset of rancidity (Çam and Kılıç, 2008). The results in our work are below these values.

\subsection{Peroxide values}

At the beginning of storage, the hazelnuts exhibited 0.00 peroxide values, and increased during storage in all varieties and reached 0.39 for Tombul, 0.30 for Kara and 0.65 for Sivri $(p<0.001)$ (Table 3). UFA concentration is one of the factors affecting the rate of oil oxidation (Çam and Kılıç, 2008). It is thought that for this reason the Sivri variety, which has the highest amount of MUFA, reached the highest peroxide value at the end of storage. In a study carried out in natural hazelnuts for 18 months, the peroxide values of the samples increased from $0.21 \%$ to $2.01 \%$ (Koç Güler et al., 2017a). In another study in which shelled hazelnuts were stored for 18 months, it increased from $0.03 \%$ to $0.62 \%$ (Turan and Islam, 2016). In a study where hazelnuts were stored for 12 months, the initial $0.05 \%$ peroxide value increased to $0.26 \%$ during storage (Ghirardello et al., 2013). In a study in which the storage stability of hazelnut flour was determined, it was reported that the peroxide value increased during storage (Evren, 2011). It is stated that rancidity is not perceived until reaching peroxide values above 2.0 in hazelnuts (Bostan and Koç Güler, 2016). Findings in our study are well below this value.

\subsection{Oxidative stability}

The oleic acid/linoleic acid value increased in all varieties at the end of the storage period $(p<.001)$. The highest $\mathrm{O} / \mathrm{L}$ value at the beginning and end of storage was determined for Sivri (11.59-12.74), 
TABLE 3. Changes in oxidative stability of the studied hazelnut varieties during storage

\begin{tabular}{|c|c|c|c|c|c|c|c|c|c|c|}
\hline \multirow[b]{2}{*}{ Parameters } & \multirow[b]{2}{*}{ Cultivar } & \multicolumn{6}{|c|}{ Period (months) } & \multirow[b]{2}{*}{$p \mathbf{p}$} & \multirow[b]{2}{*}{$p c$} & \multirow[b]{2}{*}{$p p \times p c$} \\
\hline & & $\mathbf{0}$ & 2 & 4 & 6 & 8 & 11 & & & \\
\hline \multirow{3}{*}{$\begin{array}{l}\text { Free fatty } \\
\text { acid }(\%)\end{array}$} & Tombul & $0.09 \pm 0.00 \mathrm{bB}$ & $0.11 \pm 0.03 \mathrm{bB}$ & $0.15 \pm 0.04 \mathrm{bB}$ & $0.18 \pm 0.00 \mathrm{bB}$ & $0.35 \pm 0.01 \mathrm{aA}$ & $0.45 \pm 0.06 \mathrm{aA}$ & $* * *$ & $* * *$ & $* * *$ \\
\hline & Kara & $0.11 \pm 0.03 \mathrm{bB}$ & $0.12 \pm 0.00 \mathrm{bB}$ & $0.12 \pm 0.01 \mathrm{bB}$ & $0.13 \pm 0.00 \mathrm{bB}$ & $0.37 \pm 0.01 \mathrm{aA}$ & $0.40 \pm 0.01 \mathrm{aA}$ & & & \\
\hline & Sivri & $0.20 \pm 0.01 \mathrm{aB}$ & $0.23 \pm 0.00 \mathrm{aB}$ & $0.32 \pm 0.01 \mathrm{aA}$ & $0.35 \pm 0.03 \mathrm{aA}$ & $0.37 \pm 0.01 \mathrm{aA}$ & $0.35 \pm 0.03 \mathrm{aA}$ & & & \\
\hline \multirow{3}{*}{$\begin{array}{l}\text { Peroxide } \\
\text { number } \\
\text { (meqO } / \mathrm{kg} \\
\text { oil) }\end{array}$} & Tombul & $0.00 \pm 0.00 \mathrm{aC}$ & $0.00 \pm 0.00 \mathrm{aC}$ & $0.27 \pm 0.00 \mathrm{aB}$ & $0.32 \pm 0.04 \mathrm{bAB}$ & $0.37 \pm 0.01 \mathrm{bA}$ & $0.39 \pm 0.00 \mathrm{aA}$ & $* * *$ & $* * *$ & $* * *$ \\
\hline & Kara & $0.00 \pm 0.00 \mathrm{aC}$ & $0.00 \pm 0.00 \mathrm{aC}$ & $0.00 \pm 0.00 \mathrm{bC}$ & $0.24 \pm 0.03 \mathrm{bB}$ & $0.28 \pm 0.01 \mathrm{bAB}$ & $0.30 \pm 0.00 \mathrm{aA}$ & & & \\
\hline & Sivri & $0.00 \pm 0.00 \mathrm{aD}$ & $0.00 \pm 0.00 \mathrm{aD}$ & $0.35 \pm 0.06 \mathrm{aC}$ & $0.51 \pm 0.014 \mathrm{aB}$ & $0.56 \pm 0.06 \mathrm{aAB}$ & $0.65 \pm 0.00 \mathrm{aA}$ & & & \\
\hline \multirow[t]{3}{*}{$\mathrm{O} / \mathrm{L}$} & Tombul & $9.66 \pm 0.01 \mathrm{bC}$ & $9.76 \pm 0.06 \mathrm{bC}$ & $10.64 \pm 0.01 \mathrm{bA}$ & $10.67 \pm 0.04 \mathrm{bA}$ & $10.49 \pm 0.01 \mathrm{bB}$ & $10.48 \pm 0.04 \mathrm{bB}$ & $* * *$ & $* * *$ & $* * *$ \\
\hline & Kara & $7.08 \pm 0.05 \mathrm{cBC}$ & $7.13 \pm 0.03 \mathrm{cBC}$ & $7.19 \pm 0.01 \mathrm{cAB}$ & $7.41 \pm 0.00 \mathrm{cA}$ & $6.93 \pm 0.14 \mathrm{cC}$ & $7.42 \pm 0.02 \mathrm{cA}$ & & & \\
\hline & Sivri & $11.59 \pm 0.04 \mathrm{aC}$ & $11.11 \pm 0.12 \mathrm{aD}$ & $12.85 \pm 0.15 \mathrm{aA}$ & $11.23 \pm 0.08 \mathrm{aCD}$ & $11.99 \pm 0.09 \mathrm{aB}$ & $12.74 \pm 0.03 \mathrm{aA}$ & & & \\
\hline \multirow[t]{3}{*}{ IV } & Tombul & $91.61 \pm 0.04 \mathrm{bA}$ & $91.44 \pm 0.05 \mathrm{bB}$ & $90.85 \pm 0.01 \mathrm{bD}$ & $90.70 \pm 0.01 \mathrm{bE}$ & $90.99 \pm 0.02 b C$ & $90.83 \pm 0.01 \mathrm{bD}$ & $* * *$ & $* * *$ & $* * *$ \\
\hline & Kara & $94.40 \pm 0.05 \mathrm{aBC}$ & $94.49 \pm 0.06 \mathrm{aB}$ & $94.32 \pm 0.02 \mathrm{aBCD}$ & $94.06 \pm 0.00 \mathrm{aD}$ & $94.99 \pm 0.10 \mathrm{aA}$ & $94.08 \pm 0.16 \mathrm{aCD}$ & & & \\
\hline & Sivri & $89.81 \pm 0.01 \mathrm{cB}$ & $90.24 \pm 0.12 \mathrm{cA}$ & $89.20 \pm 0.06 \mathrm{cC}$ & $90.17 \pm 0.08 \mathrm{cA}$ & $89.83 \pm 0.04 \mathrm{cB}$ & $89.57 \pm 0.00 \mathrm{cB}$ & & & \\
\hline
\end{tabular}

${ }^{*} p<0.05,{ }^{*} p<0.01, * * * p<0.001 . p_{\mathrm{p}}: p_{\text {period, }}, p_{\mathrm{c}}: p_{\text {cultivar. }}$ Values are expressed as mean \pm standard deviation of three replicates. O/L: Oleic acid / linoleic acid ratio, IV: Iodine value. Values in the same row with different capital letters (A-D) are significantly different. Values in the same column and same parameters with different lower-case letters (a-c) are significantly different. Statistical test: ANOVA and multiple comparison of means using Tukey HSD's test.

Sivri was followed by Tombul (9.66-10.48) and Kara (7.08-7.42) and the variation was statistically significant $(p<0.001)$ (Table 3). Among the varieties, the highest O/L value in Sivri was due to its highest oleic acid and lowest linoleic acid contents while the lowest value was for Kara because this variety has the lowest oleic acid and the highest linoleic acid amounts. In one study, the $\mathrm{O} / \mathrm{L}$ value was determined as 13.54-12.78 (Belviso et al., 2017) and in another study it was determined as 9.90 for Tombul, 9.00 for Kara and 11.30 for Sivri (Alasalvar et al., 2010). The oleic/linoleic ratio is an important criterion for assessing kernel quality, and a higher $\mathrm{O} / \mathrm{L}$ value means better oxidative stability (Alasalvar et al., 2010). The $\mathrm{O} / \mathrm{L}$ value increased with decreasing linoleic acid content, and the oxidative stability of all varieties increased at the end of storage. Among the varieties, it is thought that Sivri has the highest oxidative stability and storage stability at the beginning and end of storage compared to the others.

Iodine value is a measure of the degree of unsaturation of lipids. High IV is an indication that oils are more reactive, less stable and more susceptible to rancidity and oxidation (Belviso et al., 2017). The highest IV at the beginning of storage was found for Kara (94.40), followed by Tombul (91.61) and Sivri (89.81) (Table 3). At the end of storage, the Tombul's IV decreased from 91.61 to $90.83(p$ $<0.001)$, but there was no change in the Kara or Sivri $(p>0.05)$. In one study, it was determined that the IVs of natural hazelnuts were 89.84-86.94 (Belviso et al., 2017).

According to these results, it can be said that at the end of the storage period, the oxidation resistance of Tombul increased and the other varieties it did not change.

\section{CONCLUSIONS}

In this study, some chemical properties directly affecting hazelnut quality such as fatty acid composition, free fatty acid, peroxide number and oxidative stability parameters of Tombul, Kara and Sivri hazelnut varieties stored according to completely traditional methods in warehouse conditions without any air conditioning were investigated for 11 months and the findings are summarized below:

1. It was determined that in all the hazelnut varieties studied, the dominant fatty acid was oleic acid and the highest oleic acid amount was found in Sivri and the lowest in the Kara hazelnut variety. Apart from oleic acid, palmitic, stearic and linoleic fatty acids were found to be other important fatty acids and palmitoleic, arachidic, linolenic and eicosanoic acids were determined in small amounts in all the studied hazelnut varieties.

2. At the end of storage, palmitic acid had increased in Tombul, but the palmitic acid contents of the other varieties did not change. The stearic acid content increased in Tombul, was unchanged in Kara and decreased in Sivri. Oleic acid amounts increased in all the varieties while the amount of linoleic acid decreased.

3. It was observed that the amount of SFA did not change in all the varieties during storage. The amount of MUFA increased in all 
the varieties and the PUFA decreased. This decrease is thought to be due to linoleic acid peroxidation.

4. At the end of the storage period, the amount of free fatty acid and peroxide value increased in all the varieties. It is understood that the biggest factor is storage time. However, these increases are well below the rancidity perception limit. Therefore, it is not a quality reducing effect.

5. At the end of the storage period, the $\mathrm{O} / \mathrm{L}$ value increased and the IV decreased in all varieties. It is thought that oxidative stability increases with increasing $\mathrm{O} / \mathrm{L}$ value and the sensitivity to oxidative damage is decreased by a decreasing IV.

6. The hazelnut is an important food material in terms of human health and nutrition due to its high unsaturated fatty acid content, especially oleic acid. It has been determined that the ability of hazelnuts to protect human health, in particular the ability to protect cardiovascular health, has not changed much during the storage period.

7. The hard shell of the hazlenut has the ability to protect its nutritional components significantly (Anonymous, 2011). It has been observed that this property is also effective in terms of protecting fatty acids and preventing oil oxidation. Therefore, there was no significant loss in quality in the nuts.

\section{ACKNOWLEDGEMENT}

This work was supported by Ondokuz Mayis University with the project PYO. MUH.1904.10.020. This study is a part of Hasan KARAOSMANOğLU's master thesis.

\section{REFERENCES}

Alasalvar C, Amaral JS, Satır G, Shahidi F. 2009. Lipid Characteristics And Essential Minerals Of Native Turkish Hazelnut Varieties (Corylus Avellana L.). Food Chem. 113, 919-925. https://doi.org/10.1016/j.foodchem.2008.08.019

Alasalvar C, Pelvan E, Topal B. 2010. Effects of roasting on oil and fatty acid composition of Turkish hazelnut varieties (Corylus avellana L.). Int. J. Food Sci. Nutr. 61, 630-642. https://doi.org/10.3109/09637481003691820

Alasalvar C, Shahidi F, Liyanapathirana CM, Ohshima T. 2003. Turkish Tombul Hazelnut (Corylus Avellane L.): 1. Compositional Chracteristics. J. Agric. Food Chem. 51, 3790-3796. https://doi.org/10.1021/jf0212385

Anonymous. 2011. Giresun Universitesi Hayvansal ve Bitkisel Uretim Bölümü Fındık Eksperliği Programı Fındık Hasatı, Harman ve Depolanmasi Dersi Ders Notları, 250s., Giresun.

AOAC. 1990. Oils ands Fats. Official Methods of Analysis of the Association of Official Analytical Chemists, 15th. Ed., p: 485-518. Washington DC,USA

AOCS. 1990. Official Methods and Recomended Practices of The American Oil. Chemist's Society 5th Ed., American Oil Chemist Society, USA.

Belviso S, Bello BD, Giacosa S, Bertolini M, Ghirardello D, Giardano M, Rolle L, Gerbi V, Zeppa G. 2017. Chemical, mechanical and sensory monitoring of hot air- and infrared roasted hazelnuts (Corylus avellana L.) during nine months of storage. Food Chem. 217, 398-408. https://doi. org/10.1016/j.foodchem.2016.08.103

Bligh EG, Dyer WL. 1959. A rapid method for total lipid extraction and purification. Can. J. Biochem. Physiol. 37, 911917. https://doi.org/10.1139/o59-099

Bostan SZ, Koç Güler S. 2016. Kabuklu Olarak Depo Edilen Bazı Fındık Çeşitlerinde Kalite Değişimleri. Bahçe 45, 41-53.

Çam Ş, Kılıç M. 2008. Fındık Ürünlerinde Acılaşma ve Etkili Faktörler. Glda 33, 97-105.

Evren S. 2011. Naturel findik ununun depolama stabilitesi, Doctoral Dissertation, Ondokuz Mayis Üniversitesi Fen Bilimleri Enstitüsü Gıda Mühendisliği Anabilim Dalı, 136p. Samsun.

Ghirardello D, Bertolini M, Belviso S, Bello BD, Giordano M, Rolle L, Gerbi V, Antonucci M, Spigolon N, Zeppa G. 2016. Phenolic composition, antioxidant capacity and hexanal content of hazelnuts (Corylus avellana L.) as affected by different storage conditions. Postharvest Biol. Technol. 112, 95-104. https://doi.org/10.1016/j.postharvbio.2015.09.039

Ghirardello D, Contessa C, Valentini N, Zeppa G, Rolle L, Gerbi V, Botta R. 2013. Effect of storage conditions on chemical and physical characteristics of hazelnut (Corylus avellana L.). Postharvest Biol. Technol. 81, 37-43. https:// doi.org/10.1016/j.postharvbio.2013.02.014

Göncüoğlu Taş N, Gökmen V. 2015. Profiling triacylglycerols, fatty acids and tocopherols in hazelnut varieties grown in Turkey. J. Food Comp. Anal. 44, 115-121. https://doi. org/10.1016/j.jfca.2015.08.010

Gunes NT, Köksal Aİ, Artık N, Poyrazoğlu E. 2010. Biochemical Content of Hazelnut (Corylusavellana L.) Cultivars from West Black Sea Region of Turkey. Europ. J. Hort. Sci. 75, S. 77-84.

ISO. 1978. Animal and Vegetable Fats and Oils. Preparation of Methyl Esters of Fatty acids. Method ISO 5509. In İnternational Organization for Standardization. Geneve: International Organization for Standardization.

Kalkisim O, Turan A, Okcu Z, Ozdes D, 2016. Evaluation of the Effect of Different Harvest Time on the Fruit Quality of Foşa Nut. Erwerbs-Obstbau 58, https://doi.org/10.1007/ s10341-015-0259-1

Karaosmanoğlu H, Üstün NŞ. 2017. Organik ve Konvansiyonel Findıkların (Corylus avellana L.) Bazı Fiziksel Özellikleri. Akademik Gıda 15, 377-385. https://doi.org/10.24323/ akademik-gida. 370107

Koç Güler S, Bostan SZ, Çon AH. 2017a. Effects of gamma irradiation on chemical and sensory characteristics of natural hazelnut kernels. Postharvest Biol. Technol. 123, 12-21. https://doi.org/10.1016/j.postharvbio.2016.08.007

Koç Güler S, Bostan SZ, Çon AH, Șen F. 2017b. Effects of gamma irradiation treatments and storage durations on fatty acid composition of natural hazelnut kernels. Akademik Ziraat Dergisi 6, 95-100. https://doi.org/10.29278/azd.371080

Koyuncu MA. 2004. Change of Fat Content and Fatty Acid Composition of Turkish Hazelnuts (Corylus avellana L.) During Storage. J. Food Qual. 27, 304-309. https://doi. org/10.1111/j. 1745-4557.2004.00624.x

Koyuncu MA, İslam A, Küçük M. 2005. Fat and Fatty Acid Composition of Hazelnut Kernels in Vakuum Packages During Storage. Grasas Aceites 56, 263-266. https://doi. org/10.3989/gya.2005.v56.i4.91

Kurt H. 2004. Findıŏın Üretim ve Pazarlama Asamasındaki Sorunları, 3. Milli findık şurası, Giresun10-14 Ekim, 3. Milli findık şurası tebliğler kitabı, Editor: Karadeniz T, 158162, Istanbul.

Mexis SF, Kontominas MG. 2009. Effect of $\gamma$-irradiation on the physicochemical and sensory properties of hazelnuts (Corylus avellana L.). Radiat. Phys. Chem. 78, 407-413. https://doi.org/10.1016/j.radphyschem.2009.03.008

Oliveira I, Sousa A, Morais JS, Ferreira ICFR, Bento A, Estevinho L, Pereira JA. 2008. Chemical composition, and antioxidant and antimicrobial activities of three hazelnut (Corylus avellana L.) cultivars. Food Chem. Toxicol. 46, 1801-1807. https://doi.org/10.1016/j.fct.2008.01.026 
Sarıcaoğlu FT, Turhan S. 2013. Chemical composition, colour and textural properties of akçaabat meatball: a traditional Turkish meat product. GIDA 38, 191-198.

Simsek A, Aykut O. 2007. Evaluation of the microelement profile of Turkish hazelnut (Corylus avellana L.) varieties for human nutrition and health. Int. J. Food Sci. Nutr. 58, 677688. https://doi.org/10.1080/09637480701403202

Şahin İ, Erkut A, Öztek L, Üstün S, Oysun G. 1990. Orta ve Doğ $u$ Karadeniz Bölgesinde Yetistirilen Findık Ceșitlerinin
Teknolojik Özellikleri Üzerine Araștırmalar, Ondokuz Mayıs Universitesi yayınları no:63, Eser Matbaası, 54p Samsun.

Turan A, İslam A. 2016. Çakıldak Fındık Çeşidinde Kurutma Ortamları ve Muhafaza Süresine Bağlı Olarak Meydana Gelen Değisimler. Ordu Univ. J. Sci. Tech. 6, 272-285.

Turan A. 2007. Giresun İli Bulancak İlçesi Tombul Fındık Klon Seleksiyonu. Master Thesis, Ondokuz Mayis Üniversitesi Fen Bilimleri Enstitüsü, 99 p., Samsun. 